\title{
ANALISIS KEMISKINAN DAN PENDAPATAN KELUARGA NELAYAN KASUS DI KECAMATAN WEDUNG KABUPATEN DEMAK, JAWA TENGAH, INDONESIA
}

\author{
Edy Yusuf Agunggunanto \\ Fakultas Ekonomika dan Bisnis Universitas Diponegoro Semarang \\ E-mail: edy_ysf@yahoo.com.sg
}

Diterima 5 Mei 2011/Disetujui 6 Juni 2011

\begin{abstract}
The poverty of fishermen has become a critical and complex issue. The level of fishermen's poverty and income inequality are related to fishermen characteristic such as demographic, socio-economic, and sociocultural factors. The objective of this study is to analyze the poverty an income inequality of fishermen, and factors that influence it. The result of study shows fishermen experience and number of family influence income fishermen.
\end{abstract}

Keyword: poverty, inequality income, fishermen behaviour

Jumlah penduduk miskin di Indonesia sejak tahun 1976 hingga tahun 1996 senantiasa mengalami penurunan. Pada tahun 1976 jumlah penduduk miskin 54.2 juta berkurang menjadi 22.5 juta tahun 1996. Namun setelah krisis ekonomi tahun 1997, jumlah penduduk miskin bertambah menjadi 49.5 juta tahun 1998 . Berdasarkan standar 1998, pada tahun 1996 garis kemiskinan di Jawa Tengah mencapai 32.424 rupiah per kapita per bulan. Jumlah penduduk miskin pada tahun yang sama mencapai 6,4 juta jiwa atau sekitar 21,61 persen dari seluruh penduduk Jawa Tengah. Pada tahun 1999 jumlah penduduk miskin bertambah menjadi 8,8 juta atau sekitar 28,46 persen dari total penduduk Jawa Tengah. Garis kemiskinan pada tahun tersebut mencapai 76.579 rupiah per kapita.

Data BPS (dalam Jawa Tengah dalam angka 2009) menunjukkan jumlah penduduk miskin tahun 2002 menurun menjadi 7,3 juta (23,06 persen) dengan batas miskin sebesar 106.438 rupiah per kapita per bulan. Jumlah penduduk miskin tahun 2007 menurun lagi menjadi 6,56 juta $(20,43$ persen) dengan batas miskin sebesar 154.111 rupiah per kapita per bulan. Pada tahun 2008 penduduk miskin menurun menjadi 6,19 juta (19,23 persen) dengan daya batas miskin 168.168 rupiah per kapita per bulan. Pada tahun 2008, jumlah keluarga pra sejahtera di Jawa Tengah mencapai 3,10 juta atau 33,33 persen dari total keluarga. Sementara itu, untuk jumlah keluarga sejahtera I, II, III serta III plus masing - masing tercatat 1,74 juta, 2,01 juta, 2,09 juta serta 350 ribu keluarga, atau dalam presentase berturut - turut sebesar 18,79 persen, 21,63 persen, 22,49 persen dan 3,76 persen.

Kabupaten Demak yang berbatasan dengan Kota Semarang ternyata mempunyai tingkat kemiskinan yang cukup besar yaitu 23,5\% dibanding dengan Kota Semarang hany 5,26\%. Tingkat Kemiskinan ini masih di bawah rata-rata Jawa Tengah 20,43\%. (lihat Tabel 1). Keluarga pra sejahtera di Kabupaten Demak juga tercatat cujkup tinggi yaitu sebesar 48,80 \%, di atas rata-rata Jawa Tengah 33,33\% pada tahun 2008 . Tingkat pengeluaran per kapita Kabupaten Demak tersatat sebesar Rp.630.100, dibawah rata-rata Jawa Tengah sebesar Rp.633,600.

Nelayan tradisional pada umumnya hidup di bawah garis kemiskinan. Hal ini disebabkan ciri-ciri yang melekat pada mereka yaitu suatu kondisi yang subsisten, dengan modal yang kecil, teknologi yang digunakan dan kemampuan/skill serta perilaku yang tradisional baik dari segi keterampilan, psikologi dan mentalitas (Susilowati, 1991). Nelayan tradisional 
menggunakan perahu-perahu layar dalam aktivitasnya di pantai-pantai laut dangkal. Akibatnya, purata produktivitas dan pendapatannya adalah relatif rendah, di samping penangkapan di laut dangkal sudah berlebihan (over-fishing) (Susilowai 2001).

Pendapat yang sama dinyatakan oleh Akhmad Fauzi (2003), bahwa nelayan Indonesia masih tergolong miskin dengan pendapatan per kapita per bulan sekitar US \$7-10. Di samping itu degradasi lingkungan yang terjadi juga memprihatinkan. Salah satu penyebab rendahnya kinerja perikanan adalah karana terjadinya economic overfishing, bukan Malthusian overfishing. Artinya, selain rasio antar biaya dan harga yang terlalu tinggi, perikanan Indonesia sebenarnya telah mengalami overcapacity di beberapa wilayah pesisir di Indonesia. Di pantai utara Jawa, mengindikasikan bahawa kapasitas perikanan di wilayah tersebut sudah melebihi 35 peratus dari kapasiti bioeconomic optimal. Kondisi lingkungan yang rusak, jumlah nelayan yang banyak, teknologi yang masih sederhana, mengarah pada penghasilan nelayan yang rendah.

Rendahnya penghasilan nelayan tradisional merupakan masalah yang sudah lama, namun masalah ini masih belum dapat diselesaikan hingga sekarang, kerana terlalu kompleks. Hal ini tidak hanya berkaitan dengan sosioekonomi, namun berkait pula dengan lingkungan dan teknologi. Menurut Smith (1979) ada 3 kendala dalam usaha meningkatkan penghasilan nelayan tradisional, teknikal dan sosioekonomi. Kendala biologikal berhubungan dengan terhad nya stok sumber daya ikan, dan hasil tangkapan berlebih (overfishing). Kendala teknologi berhubungan dengan alat tangkap, mesin, motor atau infrastruktur pendorong lainnya seperti panjang kapal, besar dan fasilitas cold storage, atau peralatan pemprosesan yang dapat meningkatkan kualitas ikan. Kendala sosioekonomi lebih kepada nelayan sendiri dan lembaga-lembaga formal dan informal, swasta dan pemerintah yang memperlancar produksi dan distribusi.

\section{TINJAUAN PUSTAKA}

\section{Konsep Kemiskinan}

Konsep kemiskinan telah menarik minat politisi dan intelektual pada beberapa tahun lalu. (lihat Hommerlfarb, 1984, dan Woolf, 1986). Ada tiga konsep alternatif kemiskinan termasuk sebagai dasar untuk digunakan secara internasional. Secara prinsip adalah susbisten, kebutuhan dasar (basic needs) dan depriviasi relatif (relatif depriviation) (Townsend, 1993). Konsep subsisten di definisi sebagai kemiskinan, bila pendapatan mereka tidak mencukupi untuk memenuhi kebutuhan fisik hidup yang minimum. Suatu keluarga disebut miskin jika pendapatan dikurangi sewa berada di bawah garis kemiskinan. Tingkat pendapatan minimum merupakan pembatas antara keadaan miskin, dengan tidak miskin, atau sering disebut sebagai garis batas kemiskinan (Arsyad, 1992).

Konsep kemiskinan berikutnya adalah 'kebutuhan dasar' (basic needs), yang mulai dipakai pada tahun 1970 an, walau sesungguhnya gagasan ini mempunyai sejarah yang lama/panjang (Townsend, 1979). Kebutuhan dasar dapat dikelompokkan menjadi dua, pertama kebutuhan dasar yang diperlukan sekali untuk mempertahankan hidupnya,. yaitu tercukupinya makanan, perumahan dan pakaian, seperti peralatan dan perlengkapan rumah tangga. Kedua kebutuhan lainnya termasuk penyediaan pelayanan utama yang diberikan untuk masyarakat seperti air minum, sanitasi, pengangkutan umum dan kesehatan, fasilitas pendidikan dan budaya. Konsep kebutuhan dasar harus ditempatkan di dalam suatu konteks kebebasan suatu negara, martabat individu dan kebebasan individu tanpa hambatan (ILO, 1977)

Konsep ketiga kemiskinan adalah depriviasi relatif (relative deprivation), yang lebih menyeluruh dan menyangkut aspek sosial. Dalam depriviasi relatif, pendekatan ambang pendapatan perlu difahami, menurut jenis dan jumlah keluarga. Pada individu, keluarga dan masyarakat tingkat analisis kebutuhan seperti halnya jumlah dan sumber pendapatan, harus lebih menyeluruh. Perbedaan jenis kelamin, ras, umur dapat mendorong dengan kuat kepada tidak meratanya distribusi sumber daya tetapi juga ke tidak merataan distribusi permintaan yang ada di dalam keluargakeluarga tertentu, masyarakat dan kelas (Townsend, 1993). Perbedaan dalam konsep kemiskinan mengakibatkan perbedaan pengukuran kemiskinan, yang dapat digolongkan kembali pada hanya dua ukuran yang secara luas digunakan - yaitu kemiskinan 'mutlak' dan 'relatif'.

\section{Faktor-faktor yang Mempengaruhi Kemiskinan dan Pendapatan}

Beberapa faktor yang mempengaruhi kemiski- 
nan pedesaan di Indonesia termasuk adalah pertumbuhan penduduk (Chemichovsky dan Meesok, 1984; Sigit, 1985; Firdaussy, 1992; dan Booth 1992). Pertumbuhan penduduk yang cepat di pedesaan menjadi faktor utama yang mendorong kemiskinan dipedesaan Indonesia. Peningkatan penduduk dapat berdampak pada masalah penyediaan pendidikan, peningkatan pengangguran, dan masalah modal yang rendah. Selanjutnya, faktor-faktor ini secara keseluruhan memberi pengaruh pada pendapatan per kapita yang rendah penduduk pedesaan Indonesia.

Kajian Swaminathan (1997) di India yang menggunakan data panel, dengan variabel pendapatan (log) sebagai variabel bersandar, menunjukkan koefisien parameter variabel umur 0.023. Manakala koefisien parameter variabel tingkat pendidikan adalah 0.126. Kajian yang serupa dilakukan oleh Berdegue et al (2001) di Chile. Menggunakan model OLS dengan variabel bersandar adalah pendapatan dalam log, menunjukkan bahwa variabel umur tidak mempunyai pengaruh yang signifikan. Variabel pendidikan juga tidak signifikan terhadap pendapatan. Pada model probit, variabel keduanya mempunyai signifikan pada derajat 10 persen. Nilai koefisien parameter variabel umur adalah 0.02 dan variabel pendidikan adalah 0.11

Hasil temuan beberapa peneliti seperti Swaminathan (1997), Lisa (2000), Bardegue et al (2001), dan Elbers dan Lanjouw (2001), menunjukkan bahwa umur mempunyai pengaruh terhadap pendapatan. Pengaruh umur terhadap pendapatan memang tidak besar (nilai koefisien parameter antara 0.023 hingga 0.106). Walau bagaimanapun umur memang mempunyai pengaruh terhadap pendapatan. Demikian juga tingkat pendidikan mempunyai pengaruh terhadap pendapatan (Swaminathan, 1997; Lisa, 2000; Bardegue et al, 2001; Elbers dan Lanjouw, 2001; dan Naude dan Taylor, 2001). Nilai koefisien parameter variabel pendidikan antara 0.023 hingga 0.107 . Ini dapat disimpulkan bahwa pendidikan memang mempunyai pengaruh terhadap pendapatan.

Variabel lain yang mempunyai pengaruh terhadap pendapatan adalah jumlah anggota keluarga. Pengkaji-pengkaji seperti Firdaussy dan Tisdel (1992), Naude dan Taylor (2001), Elbers dan Lanjouw (2001) menggunakan variabel jumlah anggota keluarga sebagai salah satu faktor yang mempengaruhi pendapatan. Firdaussy dan Tisdel (1992) menggunakan data kerat rentas (cross section) untuk mengkaji pendapa- tan dan kemiskinan di tiga pedesaan Bali, Indonesia.

\section{Penelitian Terdahulu}

Beberapa faktor telah di klaim mempengaruhi kemiskinan pedesaan di Indonesia seperti halnya Negara Berkembang lainnya (contoh Chemichovsky dan Meesok, 1984; Sigit, 1985; Firdaussy, 1992; dan Booth 1992). Pertumbuhan cepat populasi di pedesaan sering di lihat sebagai faktor utama yang mendorong ke arah kemiskinan pedesaan. Meningkatnya tekanan populasi dapat mengarah pada masalah penyediaan pendidikan, meningkatnya pengangguran di pedesaan dan berkurangya ketersediaan modal dan secara keseluruhan mengurangi per kapita pendapa$\tan$ (Firdaussy, 1992)

Jumlah keluarga adalah suatu faktor penting yang mempengaruhi kemiskinan rumah tangga (contoh Chemichovsky Dan Meesok, 1984; Sigit, 1985; Alamgir dan Ahmed, 1988; Kuznets, 1989; Gaiha, 1989; Firdaussy, 1992). Faktor ini boleh mempengaruhi kemiskinan dalam dua arah. Pertama, mungkin secara langsung mempengaruhi kemiskinan, selama pendapatan rumah tangga tetap, meningkatnya jumlah keluarga akan menekan tingkatan konsumsi riil anggota keluarga. Kedua, sekalipun tiap anggota rumah tangga mempunyai pendapatan, pendapatan per kapita dapat menurun dengan bertambahnya jumlah keluarga berkenaan dengan diminishing marginal productivity (Sigit, 1985, Kuznet, 1989, Firdaussy, 1992)

\section{Kerangka Pemikiran}

Ciri-ciri demografi yang berhubungan dengan pendapatan nelayan dan kemiskinan meliputi : umur, tingkat pendidikan, pengalaman sebagai nelayan, jumlah keluarga dan anggota keluarga yang bekerja. Sedangkan sosio-ekonomi nelayan berkaitan dengan variabel/variabel pemilikan perahu, jenis perahu, nilai aset penangkapan ikan, nilai aset di luar aktivitas penangkapan ikan. Variabel sosio-budaya mencakup variabel institusi koperasi, hubungan dengan pemilik modal, dan perilaku nelayan.

Gambar 2 menunjukkan suatu kerangka teoritis yang mencoba menghubungkaitkan faktor-faktor demografi, sosio ekonomi dan sosio budaya terhadap pendapatan nelayan dan keluarga nelayan. Faktor demografi mencakupi beberapa variabel seperti 


\section{Gambar 1. Kerangka Teoritis}

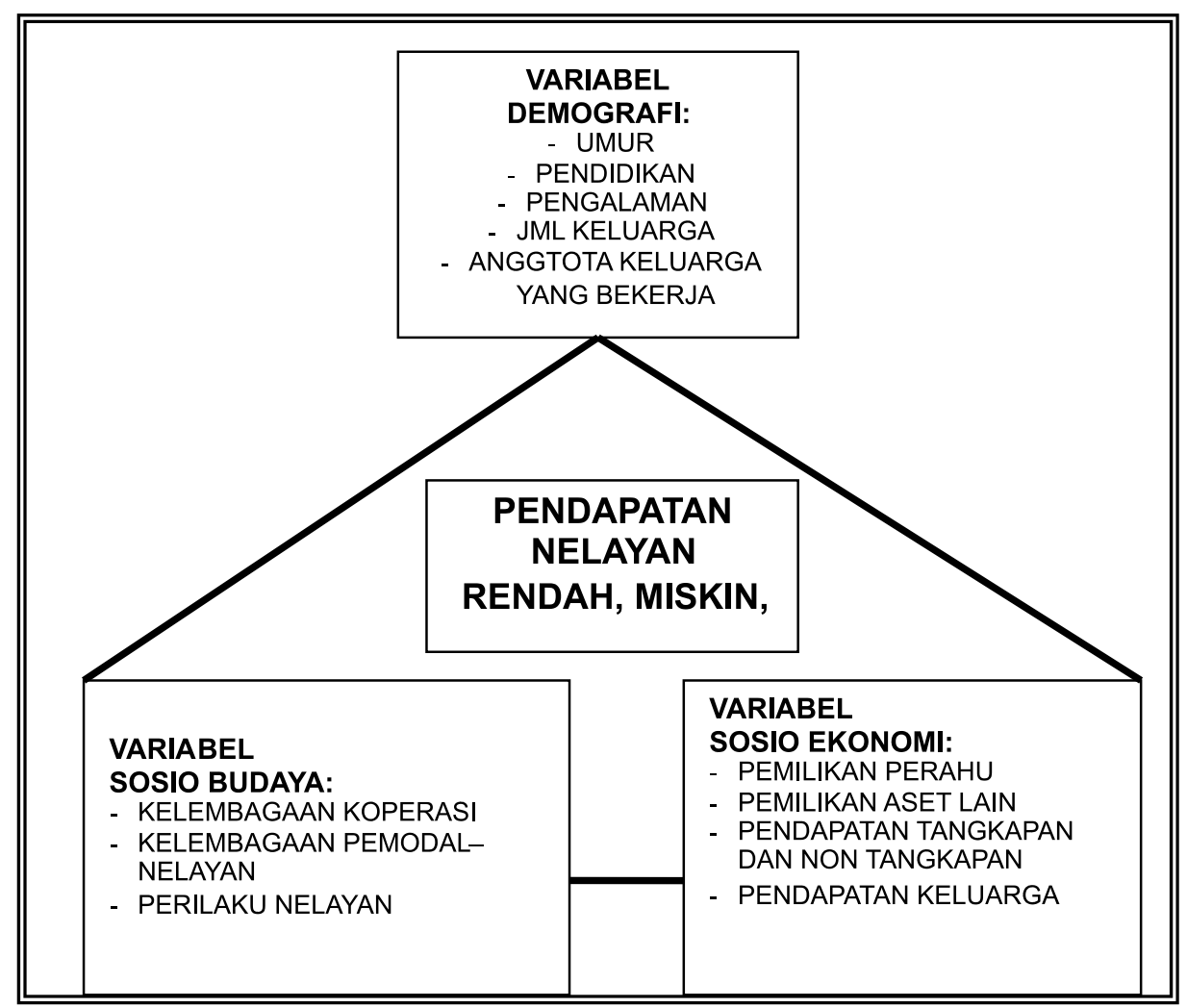

umur, tingkat pendidikan, pengalaman (lama sebagai nelayan), jumlah anggota keluarga dan anggota keluarga yang bekerja. Faktor sosio ekonomi mencakupi variabel pemilikan perahu, jenis perahu, pendapatan nelayan dan keluarga mereka. Faktor sosio budaya berkaitan dengan perilaku nelayan, institusi koperasi, hubungan nelayan dengan pemilik modal, yaitu pinjaman dan penjualan ikan.

Ada dua model regresi yang digunakan untuk analisis dalam kerangka teoritis ini, yaitu model regresi OLS dan model regresi logit. Model regresi OLS menganalisis pengaruh variabel bersandar (dependent variable) dengan variabel bebas (independent variable). Analisis regresi OLS ini akan di uraikan pada metoda analisis.

\section{Model Analisis dan Variabel yang Digunakan} kut:

Penelitian menggunakan model sebagai beri-

$$
\begin{aligned}
\log Y= & \beta_{0}+\beta_{1} X_{1}+\beta_{2} X_{2}+\beta_{3} X_{3}+\beta_{4} X_{4}+\beta_{5} X_{5} \\
& +\beta_{6} X_{6}+\beta_{7} X_{7}+\beta_{8} X_{8}+\beta_{9} X_{9}+\beta_{10} X_{10}+ \\
& \beta_{11} X_{11}+\epsilon \ldots \ldots \ldots \ldots \ldots \ldots \ldots \ldots \ldots \ldots \ldots \ldots \ldots \ldots \ldots \ldots \ldots \ldots \ldots \ldots \ldots \ldots \ldots \ldots \ldots \ldots \ldots \ldots \ldots \ldots \ldots \ldots \ldots
\end{aligned}
$$

di mana :

$\log \mathrm{Y}: \log$ pendapatan nelayan per kapita

$\beta_{0} \quad$ : intercept

$\beta_{\mathrm{i} \cdots} \ldots \beta_{\mathrm{k}}$ : koefisien parameter

$\epsilon \quad$ : error term

$\mathrm{X}_{1} \quad$ : Umur Kepala Keluarga, dalam tahun

$\mathrm{X}_{2}$ : Tingkat Pendidikan Kepala Keluarga, dengan lima tingkatan pendidikan,

1. tidak tamat pendidikan dasar,

2. pendidikan dasar (SD sederajat),

3. pendidikan menengah pertama (SMP sederajat),

4. pendidikan menengah atas (SMA sederajat), dan

5. pendidikan tinggi (diploma, sarjanar)

$\mathrm{X}_{3}$ : Pengalaman sebagai nelayan, dalam tahun

$\mathrm{X}_{4}$ : Jumlah Keluarga dalam jumlah orang

$\mathrm{X}_{5}$ : Anggota keluarga yang bekerja bekerja, dalam

jumlah orang

$\mathrm{X}_{6}$ : Pemilikan Perahu, dalam bentuk dummy,

$1=$ pemilik perahu, dan $0=$ tak memilikk perahu

$\mathrm{X}_{7}$ : Nilai aset tangkapan ikan, dalam Rupiah

$\mathrm{X}_{8}$ :Nilai aset di luar kegiatan tangkapan ikan, dalam Rupiah 
$\mathrm{X}_{9}$ : Bantuan Koperasi, dalam bentuk dummy

$1=$ Koperasi memberi bantuan kebutuhan hidup kepada nelayan

$0=$ Koperasi tidak memberi bantuan kebutuhan hidup nelayan

$\mathrm{X}_{10}$ : Jual ikan kepada tengkulak/juragan, dalam bentuk dummy

$1=$ Jual ikan kepada tengkulak

$0=$ Tidak menjual ikan kepada tengkulak

Nlai daripada koefisien parameter $\beta_{1}, \beta_{2}, \beta_{3}, \beta_{5}$, $\beta_{6}, \beta_{7}, \beta_{8}$, ialah positif, dan nilai koefisien paramater lainnya iaitu $\beta_{4}, \beta_{9}$ dan $\beta_{10}$ mempunyai nilai negatif.

Selain model regresi OLS di atas, maka kajian ini juga menggunakan model regresi logit. Kaedah regresi logit digunakan apabila pembolehubah tak bebas (dependent variables) adalah bilangan nonparametrik kategorikal (mempunyai nilai 1 dan nilai 0) dan pembolehubah bebas (independent variables) adalah satu atau lebih bilangan parametrik dan nonparametrik berikut :

Rumusan model regresi logit kajian ini seperti

$$
\begin{aligned}
& \ln \frac{r}{1-r}=\beta_{0}+\beta_{1} X_{1}+\beta_{2} X_{2}+\beta_{3} X_{3}+\beta_{4} X_{4}+ \\
& \beta_{5} X_{5}+\beta_{6} X_{6}+\beta_{7} X_{7}+\beta_{8} X_{8}+\beta_{9} X_{9}+ \\
& \beta_{10} X_{10}+\beta_{11} X_{11}
\end{aligned}
$$

di mana :

$$
\begin{array}{ll}
\rho & : \text { probabilitas kemiskinan, } \\
& \text { miskin }=1 \text { dan tak miskin }=0 \\
\beta_{0} & : \text { intercept } \\
\beta_{\mathrm{i} \ldots \beta_{\mathrm{k}}}: & \text { koefisien parameter } \\
\epsilon & : \text { error term }
\end{array}
$$

Nilai daripada koefisien parameter $\beta_{1}, \beta_{2}, \beta_{3}, \beta_{5}$, $\beta_{6}, \beta_{7}, \beta_{8}$, ialah negatif, dan nilai koefisien pamater lainnya iaitu $\beta_{4}, \beta_{9}$ dan $\beta_{10}$ mempunyai nilai positif.

\section{HASIL DAN PEMBAHASAN}

Sebelum menganalisis model regresi OLS dan regresi logit, maka perlu dilakukan beberapa uji statistik seperti uji statistik multikolineariti dan heteroskedasitisi. Selepas lulus uji statistik ini, maka tingkatan berikutnya adalah uji statistik ketepatan padanan (goodness of fit) dan terakhir adalah uji statistik t pengaruh variabel bebas ke atas pemboleh bersandar.

\section{Uji statistik Multikolinearitas}

Untuk mengesan ada tidaknya multikolineariti dalam sebuah model persamaan regresi, maka digunakan beberapa ukuran, iaitu dari nilai VIF (Variance Inflation Factor). Tidak wujud multikolineariti apabila nilai VIF di bawah 10. Selain itu, untuk melihat wujud atau tidak multikolineariti, dapat juga di lihat dari nilai kritis (cut-off) dan nilai toleransi (tolerance). Apabila nilai toleransi di bawah 0.10 maka dapat dinyatakan tidak ada multikolineariti. Perhitungan nilai VIF dan nilai toleransi diperoleh dari penghitungan dengan program SPSS. Hasil perhitungan menunjukkan bahawa tidak ada multikolineariti dalam model regresi (Tabel 5.20).

Tabel 1 menunjukkan bahawa nilai toleransi variabel dalam model regresi mempunyai nilai di bawah 0.10. Julat nilai toleransi variabel berada antara 0.55 hingga 0.891 , yang mempunyai nilai rendah adalah variabel umur (0.255), sedangkan yang tertinggi adalah variabel dummy jualan ikan ke pemilik modal, bernilai 0.891. Manakala uji statistik multikolineariti dilihat dari nilai VIF, maka boleh dikatakan bahawa telah lulus uji statistik. Semua variabel mempunyai nilai VIF di bawah 10, nilai VIF mempunyai julat antara 1.123 (untuk variabel dummy jualan ikan kepada pemilik modal) hingga 3.925 (untuk variabel umur)

Tabel 1. Uji statistik Multikolineariti Menggunakan Nilai Toleransi dan VIF

\begin{tabular}{llcc}
\hline \multirow{2}{*}{ Variabel } & \multicolumn{2}{c}{ Collinearity Statistics } \\
\cline { 3 - 4 } & & Tolerance & VIF \\
\hline $\mathrm{X}_{1}$ & Umur & .255 & 3.925 \\
$\mathrm{X}_{2}$ & Tingkat Pendidikan Responden & .842 & 1.188 \\
$\mathrm{X}_{3}$ & Pengalaman menjadi nelayan & .337 & 2.964 \\
$\mathrm{X}_{4}$ & Jumlah anggota Keluarga & .563 & 1.775 \\
$\mathrm{X}_{5}$ & Jumlah angota keluarga bekerja & .608 & 1.646 \\
$\mathrm{X}_{6}$ & Pemilikan Bot/Kapal & .297 & 3.372 \\
$\mathrm{X}_{7}$ & Nilai aset alat tangkap ikan & .461 & 2.168 \\
$\mathrm{X}_{8}$ & Nilai Aset di luar aktiviti & .758 & 1.319 \\
$\mathrm{X}_{9}$ & Dumgkapan ikan & .873 & 1.145 \\
$\mathrm{X}_{10}$ & Dummy bantuan koperasi & .891 & 1.123 \\
\hline Sumber: data olahan kajian & &
\end{tabular}




\section{Uji statistik Normalitas}

Distribusi normal multivariat adalah elemen utama dalam teknik statistik multivariat. Kebanyakan teknik statistik mempunyai andaian bahawa data dan variabel multivariat rawak (multivariate random variable), mempunyai taburan ke arah taburan multivariat normal (multivariate distribution normal). Uji statistik normaliti dapat menggunakan analisis gambar dan nilai daripada skewness dan kurtosis. Data mempunyai taburan normal apabila nikai skewness $=$ 0 dan kurtotis tidak lebih dari 3 (Aczel,1999)

Kajian mendapati, data mempunyai taburan normal, yang ditunjukkan oleh Gambar yang mempunyai taburan normal dan nilai daripada skewness sama dengan 0 dan kurtosis yang kurang daripada 3 (Gambar 2)

\section{Uji statistik Heteroskedastisiti (heteroscedasticity)}

Uji statistik heteroskedastisiti pada kajian ini menggunakan uji statistik White (White test). Uji statistik heteroskedastisiti yang dicadangkan oleh White tidak memerlukan andaian normaliti dan mudah penerapannya (implementation). Uji statistik ini dapat dilakukan dengan melakukan regresi kuasa dua residual (residual square $-\mu^{2}$ ) dengan variabel bebas asal $\left(\mathrm{X}_{\mathrm{i}}\right)$. Model regresi bantuan (auxiliry reegression) ini akan mendapatkan nilai $\mathrm{R}^{2}$.

Hipotesis null bahawa tidak ada heteroskedatisiti dapat ditunjukkan ke atas perkalian saiz sampel (n) dengan $\mathrm{R}^{2}$ asympotically mengikuti nilai chi-square.
Apabila nilai chi-square yang diperoleh lebih besar dari nilai kritis chi-square pada tingkat signifikan yang ditetapkan,maka wujud heteroskedastisiti. Sebaliknya apabila lebih rendah dari nilai kritis chi-square, maka tidak ada heteroskedastisiti (Gujarati, 2003). Kajian ini menggunakan program statistik eViews5 untuk uji statistik White. Uji statistik mendapati nilai (obs * $\left.\mathrm{R}^{2}\right) 34.97404$ dengan probabiliti 0.014 yang menunjukkan bahawa tidak ada heteroskedastisiti (Tabel 2)

Tabel 2. Uji statistik White Heteroskedastisiti

\begin{tabular}{llll}
\hline F-statistic & 2.007763 & Prob. F(20,179) & 0.009999 \\
Obs*R-squared & 34.97404 & Prob. Chi-Square(20) & 0.014068 \\
\hline
\end{tabular}

Sumber: data olahan kajian

\section{Uji Statistik Ketepatan Padanan (Goodness of Fit)}

Uji statistik statistik F biasanya digunakan untuk menguji ketepatan padanan pada model regresi OLS. Nilai statistik F yang tinggi dengan tingkat signifikan kurang dari 0.05 memberikan petunjuk bahawa model regresi yang dianalisis merupakan model yang baik. Uji statistik statistik $\mathrm{F}$ dalam kajian mendapati nilai $\mathrm{F}$ bernilai $18.63949(p=0.000<0.05)$ yang menunjukkan bahawa model regresi telah lulus dari ujan F, dan dapat dilakukan analisis seterusnya.

Manakala bagi model regresi logit, uji statistik ketepatan padanan digunakan nilai Statistik $L R$ (Nisbah kebolehjadian - Likelihood Ratio) pada tingkat signifikan 0.05 . Nilai statistik LR yang tinggi dan tingkat signifikan kurang dari 0.05 menunjukkan bahawa model yang dianalisis sudah sesuai, atau telah

Gambar 2. Nilai Skewness, Kurtosis dan Taburan Data

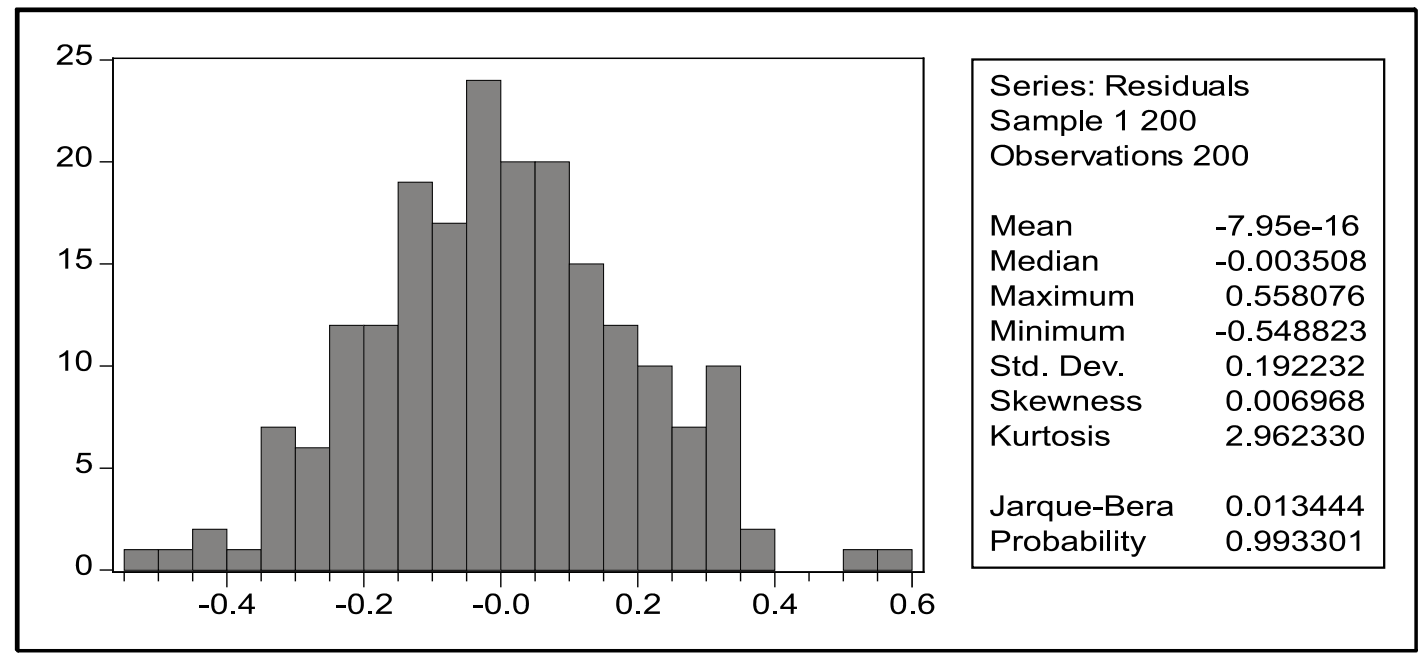

Sumber: data olahan kajian 
lulus uji statistik ketepatan padanan. Menggunakan program eViews, didapati nilai statistik LR sebesar $93.65856(\mathrm{p}=0.00<0.05)$ yang bermakna uji statistik ketepatan padanan dapat diterima, model telah sesuai untuk digunakan analisis berikutnya. Selain dari pada statistik LR, uji statistik ketepatan padanan model regresi logit dapat pula digunakan uji statistik Hosmer-Lemeshow. Nilai Hosmer-Lemeshow yang kecil menunjukkan perbezaan yang kecil antara data sebenar dengan data yang dijangka atau expected, dengan tingkat signifikan 0.05 . Apabila nilai Hosmer-Lemeshow dan tingkat signifikan lebih dari 0.05, maka model telah lulus uji statistik ketepatan padanan. Kajian mendapati nilai Hosmer-Lemeshow ( $p=0.09$ $>0.05$ ) memberikan petunjuk bahawa model dapat digunakan sudah sesuai dan dapat digunakan untuk analisis berikutnya. Uji statistik Hosmer-Lemesshow pada lampiran D.

Uji statistik statistik $\mathrm{t}$

Uji statistik $t$ digunakan untuk menguji hipote- sis null tidak ada hubungan antara variabel bebas ke atas variabel bersandar. Uji statistik ini menguji

$$
\begin{aligned}
& \mathrm{H}_{0}: \beta_{\mathrm{j}}=0 \\
& \mathrm{H}_{\mathrm{a}}: \beta_{\mathrm{j}} \neq 0
\end{aligned}
$$

Uji statistik $t$ digunakan $t$ dua hujung (two tail test) untuk mengetahui pengaruh di antara variabel, sama ada pengaruh di antara variabel itu signifikan atau tidak. Uji statistik t ini merupakan uji statistik hipotesis, sehingga hipotesis yang dibentuk dalam kajian ini diterima atau ditolak. Uji statistik $t$ ini menggunakan tingkat keertian 0.05 dan 0.10. Apabila nilai statistik $\mathrm{t}$ lebih besar dari pada nilai kritikal $\mathrm{t}(t$ table) pada tingkat signifikan 0.05 dan 0.10 , maka uji statistik $t$ diterima $(p<0.05$ dan $p<0.10)$. Oleh itu apabila nilai probabiliti uji statistik statistik $\mathrm{t}$ kurang dari pada 0.05 dan 0.10 , maka hipotesis null diterima, iaitu tidak ada pengaruh variabel bebas ke atas variabel bersandar. Dengan lain kata menerima hipotesis alternatif iaitu ada pengaruh variabel bebas ke atas variabel bersandar.

Tabel 3. Model regresi OLS dan regresi Logit

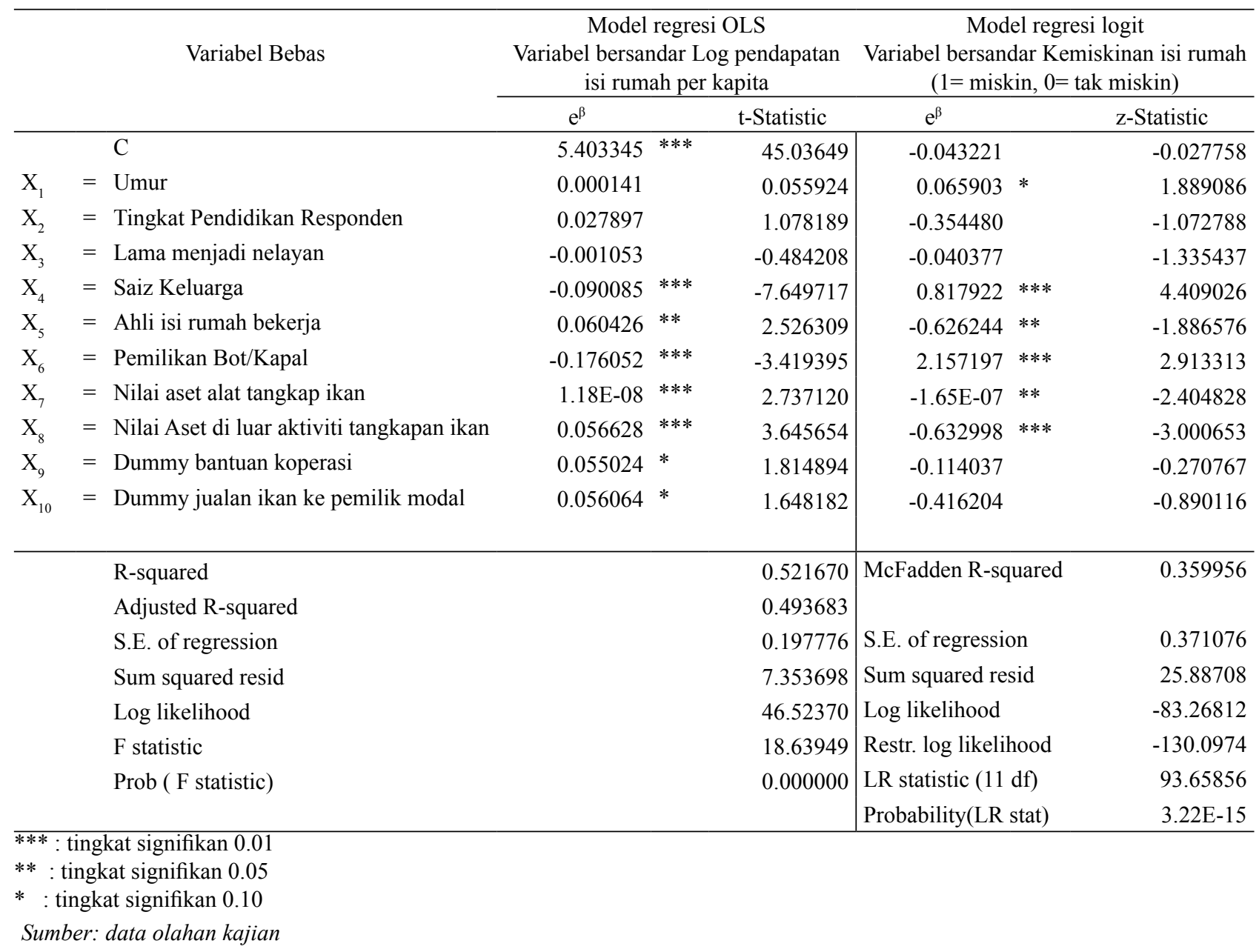


Tabel 3 menunjukkan beberapa variabel bebas yang diterima mempunyai hubungan dengan variabel bersandar, sama ada pada model regresi OLS maupun regresi logit. Pada model regresi OLS ada tiga variabel bebas yang tidak diterima dalam uji statistik $\mathrm{t}$, iaitu variabel $\mathrm{X}_{1}$ (umur responden), $\mathrm{X}_{2}$ (tingkat pendidikan responden), dan $\mathrm{X}_{3}$ (pengalaman responden sebagai nelayan). Variabel bebas lainnya yang diterima iaitu $\mathrm{X}_{4}$ (saiz keluarga), $\mathrm{X}_{5}$ (ahli isi rumah bekerja), $\mathrm{X}_{6}$ (pemilikan bot/kapal), $\mathrm{X}_{7}$ (nilai aset alat tangkapan ikan), $X_{8}$ (nilai aset di luar aktiviti tangkapan ikan). $\mathrm{X}_{9}$ (dummy bantuan koperasi), dan $\mathrm{X}_{10}$ (dummy jualan ikan ke pemilik modal).

Manakala pada model regresi logit, ada empat variabel yang tidak signifikan, iaitu variabel iaitu variabel $\mathrm{X}_{3}$ (pengalaman responden sebagai nelayan), $\mathrm{X}_{4}$ (saiz keluarga), $\mathrm{X}_{9}$ (dummy bantuan koperasi), dan $\mathrm{X}_{10}$ (dummy jualan ikan ke pemilik modal). Variabel lainnya yang signifikan iaitu variabel $\mathrm{X}_{2}$ (tingkat pendidikan responden), $\mathrm{X}_{5}$ (ahli isi rumah bekerja), $\mathrm{X}_{6}$ (pemilikan bot/kapal), $\mathrm{X}_{8}$ (nilai aset alat tangkapan ikan), $X_{9}$ (nilai aset di luar aktiviti tangkapan ikan), seperti ditunjukkan pada Tabel 3.

\section{KESIMPULAN DAN SARAN}

\section{Kesimpulan}

Penelitian menunjukkan beberapa kesimpulan sebagai berikut:

- Pengalaman sebagai nelayan secara langsung maupun tidak, memberi pengaruh kepada hasil penangkapan ikan. Semakin lama seseorang mempunyai pengalaman sebagai nelayan, semakin besar hasil dari penangkapan ikan dan pendapatan yang diperoleh.

\section{DAFTAR PUSTAKA}

Adger, W. Neil, 1999,"Exploring Income Inequality in Rural, Coastal Vietnam", The Journal of Development Studies, vol. 35 no.5 Jun, pp.96-119

Akhmad Fauzi, 2003."Turning the Tide" Kebijakan Ekonomi Perikanan, Kompas 30 Julai 2003 hal 35.

Alamgir, M and A. Achmed, 1988, “ Poverty and Income distribution in Bangladesh, in: T.N. Srinivasan and P.K. Bardhan, eds., Rural Poverty in South Asia, Columbia University Press, pp. 11-38
- Jumlah anggota keluarga yang bekerja ternyata mempunyai pengaruh terhadap pendapatan keluarga. Peran anggota keluarga sangat membantu dalam meningkatkan pendapatan keluarga.

- Kegiatan penangkapan ikan dengan menggunakan teknologi penangkapan ikan yang berbeda dapat mempengaruhi produksi penangkapan ikan. Informasi dan penerapkan teknologi baru bagi nelayan lain merupakan sarana untuk meningkatkan kemampuan dan pengelolaan sumberdaya ikan.

- Perilaku nelayan yang mengambil terumbu karang sangat merugikan nelayan sendiri. Pengambilan terumbu karang yang berterusan pasti merusak habitat ikan utamanya tempat ikan berkembang sehingga akan menguragi hasil tangkapan mereka.

\section{Saran}

Peningkatan pendapatan nelayan untuk mengurangi tingkat kemiskinan yang dialami masyarakat nelayan dapat dilakukan dengan beberapa alternatif, anatra lain:

- Meningkatkan ketrampilan dan pengalaman dalam proses penangkapan ikan. Hal ini dapat dilakukan dengan memperkenalkan kepada keluarga dan anak-anak mereka cara menangkap ikan yang lebih baik.

- Penyadaran akan pentingnya pemeliharaan lingkungan untuk menjaga ekosistem atau tempat berkembang biak ikan.

- Meningkatkan kinerja koperasi agar dapat membantu nelayan dalam penyediaan kebutuhan nelayan melaut serta pembelian hasil tangkapan ikan.

Arsyad, Lincolin, 1992, "Memahami Masalah Kemiskinan di Indonesia: Suatu Pengantar", Jurnal Ekonomi dan Bisnis Indonesia, no. 1 tahun vii, pp.95 - 116. Atkinson, A.B, 1970, "On the Measurument of Inequality", Journal of Economic Theory, vo. 2, 1970

Booth, A, 1992, "Income Distribution and Poverty" in A. Booth, ed The Oil Boom and After: Indonesian Economic Policy and Perfdormance During the Soeharto Era. Singapore; Oxford University Press, 321-362 
Cancian, Maria and Reed, Deborah, 1999, "Impact of Wive's Earnings on Income Inequality: Issues and Estimates", Demography, vol. 38, no. 2, May 1999 pp. $173-184$

Chandel, B.S and Sharma, R.K, 1989, "Rural Poverty in Himachal Pradesh - A Study of Kangra Farms", Indian Journal of Economics, vol.lxx, Oct, pp.135-140.

Estudillo, J.P, 1997, "Income inequality in The Philippines, 1961 - 1991", The Developing Economies, vol. xxxv. no.1,March, pp.68-95

Firdaussy, CM and Tisdell, Clem, 1992. "Determinant of Rural Income and Poverty at The Village Level in Bali, Indonesia", Malaysian Journal of Economic Studies, vol.xxix, no. 1 (June 1992) pp.19-34.

Gaiha, R., 1987, "Inequality, Earning and Participation Among the Poor in Rural India, The Journal of Developmenmt Studies, vol.23, July 1987, pp.491508

Gujarati, D.N, 2003, Basic Economitrics, fourth edition, Mc. Graw Hill.

Kakwani, Nanak C, 1980, Income Inequality and Poverty, Methodsof Estimation and Policy Apllications, Oxfor Press University.

Lerman, Roberty I and Yitzhaki, Shlomo, 1985, “ Income Inequality Effects byu Income Sources: A New Approach and Application to the United States", The Reeview of Economics and Statistics, volume 67, issue 1 (Feb., 1985), pp.151-156
Mukherjee, Nilanjana, 1999.”Consultations With The Poor in Indonesia, country synthesis report, draft report August 1999 Wolrd Bank

Susilowati, Indah, 1991, "Welfare Impact of Improved Boat Modernisation in Pemalang Regencies, Central Java, Indonesia", Master Thesis, The Faculty of Economics and Management,University Putra Malaysia

Susilowati, Indah, 2001, Kajian Partisipasi Wanita dan Istri Nelayan Dalam Membangun Masyarakat Pesisir (Studi Kasus pada Perkampungan Nelayan di Demak, Jawa Tengah), Laporan Penelitian, Kerjasama UNDIP dengan Mc Master Univeristy Canada.

Swaminathan, M., 1997," The determinant of Earning Among Low-Income Workers inBombay: An Analysis of Panel Data", The journal of Development Studies, vol. 33, no.4, April, pp.535551

Townsend, P, (ed.), 1970, The Concepts of Poverty, London, Heinemann 